\title{
LEGITIMIDADE ATIVA DO PARTIDO POLÍTICO NO MANDADO DE SEGURANÇA COLETIVO: UMA PROPOSTA DE RELEITURA À LUZ DA CONSTITUIÇÃO DE 1988
}

\author{
POLITICAL PARTY'S STANDING TO SEEK “MANDADO DE SEGURANÇA COLETIVO”: A \\ REREADING IN THE LIGHT OF THE CONSTITUTION OF 1988
}

Fábio Lima Quintas

\begin{abstract}
Doutor em Direito do Estado pela Faculdade de Direito da Universidade de São Paulo (USP) Professor doMestrado Acadêmico em Direito Constitucional da Escola de Direito de Brasília (EDB) do Instituto Brasiliense de Direito Público (IDP). E-mail: fabioquintas@idp.edu.br
\end{abstract}

João Paulo Sousa Mendes

Especialista em Direito Processual Civil e Bacharel em Direito pela Escola de Direito de Brasília (EDB) do Instituto Brasiliense de Direito Público (IDP).

E-mail: joao_ps_mendes@hotmail.com

Recebido em: 09/04/2019

Aprovado em: 05/05/2019

\begin{abstract}
RESUMO: A possibilidade de se impetrar mandado de segurança coletivo tornou-se expressa no ordenamento jurídico brasileiro a partir do disposto no art. $5^{\circ}$, inciso LXX, da Constituição Federal de 1988, cuja alínea "a", conferiu legitimidade ao partido político. No entanto, a Constituição não definiu os limites da legitimidade ativa do partido político. A Lei $\mathrm{n}^{\mathbf{0}}$ 12.016, de 2009, primeira regulamentação infraconstitucional do mandado de segurança coletivo limitou a legitimidade ativa do partido político à tutela de direitos ou interesses coletivos e individuais homogêneos relativos a seus filiados ou à finalidade partidária. Sendo assim, busca-se aferir, em vista do papel desempenhado pelos partidos políticos no nosso sistema jurídico e político, da origem desse instrumento processual na Constituição Federal de 1988 e do chamado microssistema de tutela de direitos e interesses coletivos, em que medida o art. 21 da Lei no 12.016, de 2009, é compatível com a Constituição Federal de 1988. Para tanto, a fim de analisar a questão, do ponto de vista dogmático, foi realizada revisitação às bases históricas dos trabalhos efetuados na Assembleia Nacional Constituinte de 1987 e exame dos textos constitucional e infraconstitucional, dialogandoos com a doutrina e a jurisprudência.
\end{abstract}

Palavras-chave: Mandado de segurança coletivo. Partido político. Legitimidade ativa. Direitos coletivos.

ABSTRACT: The possibility of seeking mandado de segurançacoletivo has been expressed in the Brazilian legal system in the article $5^{\text {th }}$, item LXX, of the Federal Constitution of 1988, whose sub item "a" has granted standing to political party. However, the Constitution did not define the limits of the political party's standing. The Rule 12,016, of 2009, the first infra-constitutional regulation of the mandado de segurançacoletivo, has limited the political party's standing only to seek the protection of collective rights related to its affiliates or related to the party purpose. Thus, in view 
of the role played by political parties in our legal and political system, the origin of this writ in the Federal Constitution of 1988, and the called micro-system of protection of collective rights, it is sought to verify the extent the article 21 of the Rule 12,016, of 2009, is compatible with the Federal Constitution of 1988. In order to analyze the question, from a dogmatic point of view, a revision was made to the historical bases of the work carried out in the National Constituent Assembly of 1987 and examination of constitutional and infra-constitutional texts, dialoguing with doctrine and jurisprudence.

Key words: Mandado de segurança coletivo. Political party. Standing. Collective rights.

SUMÁRIO: Introdução; 10 mandado de segurança coletivo na Constituinte; 2 Uma visão sobre o papel institucional do partido político na Constituição de 1988; 3 Os aspectos processuais da controvérsia acerca da legitimidade do partido político para impetrar mandado de segurança coletivo; 4 Uma visão crítica sobre a legitimidade dos partidos políticos para impetrar mandado de segurança coletivo, no regime da Lei nº 12.016, de 2009; Conclusão; Referências.

\section{INTRODUÇÃO}

A Constituição Federal de 1988 ampliou o rol dos denominados remédios constitucionais, a fim de ampliar o acesso à justiça e de garantir a observância dos direitos e garantias fundamentais. Entre os remédios constitucionais inéditos estão o habeas data e o mandado de injunção. Além disso, a Constituição passou a prever, expressamente, a possibilidade de se impetrar mandado de segurança coletivo.

Quanto ao mandado de segurança coletivo, a Constituição Federal de 1988 restringiu-se a prever legitimados a impetrá-lo (art. $5^{\circ}$, inciso LXX): a) partido político com representação no Congresso Nacional; e b) organização sindical, entidade de classe ou associação legalmente constituída e em funcionamento há pelo menos um ano, em defesa dos interesses de seus membros ou associados.

No ano de 2009, entrou em vigor a Lei $\mathrm{n}^{\mathbf{0}} 12.016$, para regulamentar o mandado de segurança individual e coletivo, superando a legislação pré-constitucional existente (a Lei $\mathrm{n}^{\circ} 1.533$, de 1951). Além de buscar atualizar o instituto para os novos tempos constitucionais, trata-se da primeira regulamentação infraconstitucional do mandado de segurança coletivo. Nesse aspecto, a nova lei, ao tratar dos legitimados, estabeleceu que poderia impetrar o writ coletivo o partido político com representação no Congresso Nacional, "na defesa de seus interesses legítimos relativos a seus integrantes ou à finalidade partidária" (art. 21). Ademais, a lei prevê que são passíveis de tutela por meio do mandado de segurança coletivo os direitos coletivos em sentido estrito e os direitos individuais homogêneos (art. 21, parágrafo único). Essas limitações, no entanto, não encontram previsão constitucional.

A questão que se põe, nesse contexto, é saber, primeiramente, se são legítimas as restrições contidas na legislação infraconstitucional acerca do cabimento do mandado de segurança coletivo impetrado por partido político.

A resposta dessa questão, do ponto de vista dogmático, demanda examinar as raízes históricas do mandado de segurança coletivo, o texto constitucional, sua relação com a legislação infraconstitucional, no contexto anterior e posterior à Lei ${ }^{\circ}{ }^{\circ} 12.016$, de 2009, e a leitura que a doutrina e os Tribunais (Superior Tribunal de Justiça e Supremo Tribunal Federal) deram ao assunto ao longo desse período. Decerto, o enfrentamento dessas questões exige enfrentar não apenas questões processuais, mas, também, o papel desempenhado pelos partidos políticos no nosso sistema jurídico e político.

Nesse sentido, assume-se que a compreensão do direito deve levar em consideração não 
somente a norma jurídica, mas também a percepção tida pelo intérprete da norma, isto é, o entendimento e alcance que as autoridades conferem a ela, bem como a prática social em que a norma se desenvolve ${ }^{1}$.

Interessante observar que, nesses trinta anos desde a promulgação da Constituição, não há ainda, sobre o assunto, uma definição na doutrina ou na jurisprudência do Superior Tribunal de Justiça e do Supremo Tribunal Federal acerca dos limites da legitimidade ativa do partido político, não obstante seja possível identificar, sobretudo a partir da Lei n ${ }^{\circ} 12.016$, de 2009, uma postura restritiva a respeito do assunto.

\section{MANDADO DE SEGURANÇA COLETIVO NA CONSTITUINTE}

A instituição da modalidade coletiva do mandado de segurança, inovação trazida pela Constituição de 1988, certamente pode ser situada numa discussão mais abrangente, acerca do acesso à justiça. De fato, como bem diagnosticaram Mauro Cappelletti e Bryant Garth (1998, p. 18-19), em estudo clássico sobre o tema, em certo momento histórico constatou-se a insuficiência do processo civil para tratar de conflitos coletivos, o que exigiu da legislação e da prática processual a necessidade de repensar institutos processuais clássicos, como legitimidade e coisa julgada (DIDIER JR.; ZANETI JR., 2012, p. 33-34; BARBI, 2009, p. 267-268)². E, nesse cenário de aperfeiçoamento dos institutos processuais (MENDES, 2014, p. 33-44), hoje se fala na existência de um verdadeiro microssistema de tutela dos direitos ou interesses coletivos (DIDIER JR.; ZANETI JR., 2012, p. 51-55).

No plano histórico, a adequada compreensão sobre o mandado de segurança coletivo demanda incursão na evolução da deliberação quanto ao texto final do art. $5^{\circ}$, inciso LXX, da Constituição Federal de 1988, ao longo dos trabalhos realizados na Assembleia Nacional Constituinte (ANC) de $1987^{3}$.

Costuma-se dividir os trabalhos da Assembleia Nacional Constituinte de 1987 em 7 etapas: i) Preliminar; ii) Subcomissões Temáticas; iii) Comissões Temáticas; iv) Comissão de

\footnotetext{
${ }^{1}$ Sobre o assunto, comenta Fábio Lima Quintas (2011, p. 259-260) que "o direito tem a pretensão de ser uma ordem normativa. Ordem não propriamente no sentido de comando, mas no sentido de ordenação: o estabelecimento de um padrão estipulado, que seja racionalmente inteligível em sua totalidade. De fato, o direito não existe apenas como expressão da autoridade e da coerção. O direito existe como realidade própria na qual se manifesta práticas sociais convergentes orientadas por um critério explicativo e regulativo, por meio do qual as pessoas identificam padrões de funcionamento. O Direito é mais do que mera aceitação e subordinação: é um critério regulador de conduta. Essa dimensão é percebida quando se analisa o direito na perspectiva do usuário da norma (o cidadão, os agentes públicos etc), que busca se orientar a partir de uma ordem normativa que lhe é imposta institucionalmente (na medida em que está assentada num sistema de regras que estabelece como o direito é formado e implementado). Existe, pois, uma dimensão do ordenamento jurídico que não pode ser compreendida apenas como sistema de coerção. Significa dizer que o direito - antes de ordenar, comandar - precisa orientar a conduta, definindo padrões sobre o que seja certo e errado. Aqui temos a proposição do direito como verdadeiro ordenamento jurídico"

Ainda sobre o tema, conferir o texto "Um ensaio sobre a função da lei no Estado Democrático de Direito: uma reflexão a partir da obra de Neil MacCormick" (QUINTAS, 2014).

${ }^{2}$ Celso Agrícola Barbi (2009, p. 267-268) cita o exemplo da tutela de direitos subjetivos individuais mediante litisconsórcio ativo facultativo. O trâmite processual nesses casos em que havia o denominado litisconsórcio multitudinário poderia se tornar caótico. Certamente em razão disso, o art. 46, parágrafo único, do Código de Processo Civil de 1973, com a redação dada pela Lei $\mathrm{n}^{\circ}$ 8.952, de 1994, passou a prever a possibilidade de que o juiz pudesse limitar a quantidade de litisconsortes, a fim de evitar o comprometimento da defesa e da razoável duração do processo. Eis a redação do dispositivo: "O juiz poderá limitar o litisconsórcio facultativo quanto ao número de litigantes, quando este comprometer a rápida solução do litígio ou dificultar a defesa".

${ }^{3}$ Cumpre mencionar que, anteriormente ao próprio início dos trabalhos da Assembleia Nacional Constituinte de 1987, foi instaurada pelo Poder Executivo comissão provisória para elaborar o anteprojeto de Constituição. Tal comissão veio a ser conhecida como "Comissão Afonso Arinos", por ter sido presidida pelo então Senador Afonso Arinos. No entanto, no anteprojeto da comissão, não havia qualquer dispositivo tratando do mandado de segurança coletivo.
}

Revista de Direito Brasileira | Florianópolis, SC | v. 23 | n. 9 | p.63-82 |Mai./Ago. 2019 
Sistematização; v) Plenário; vi) Comissão de Redação; e vii) Epílogo(OLIVEIRA, 1993).

$\mathrm{Na}$ Etapa Preliminar (Etapa 1), foi definido o Regimento Interno da Assembleia Nacional Constituinte e foram reunidas as sugestões de cidadãos, dos Constituintes e de entidades.

Após as sugestões de redação dadas pelos cidadãos, Constituintes e entidades, iniciou-se a Etapa 2, na qual foi consolidado o Anteprojeto do Relator da Subcomissão dos Direitos Políticos, dos Direitos Coletivos e Garantias, Deputado Lysâneas Maciel, o qual previa o instituto do mandado de segurança coletivo (BRASIL, 1987, p. 12):

Art. 36. Conceder-se-á mandado de segurança coletivo para proteger direito líquido e certo não amparado por "habeas corpus", seja o responsável pela ilegalidade, ou abuso de poder, pessoa física ou Jurídica, de direito público ou privado.

Diante dessa redação, o Deputado Federal Uldurico Pinto apresentou emenda, sugerindo que o mandado de segurança individual e o mandado de segurança coletivo fossem alocados no mesmo dispositivo (BRASIL, 1987, p. 129-130):

Conceder-se-á mandado de segurança para proteger direito ou interesse, individual ou coletivo, concreto ou difuso, baseado em fato certo e determinado, devidamente comprovado, não amparado por habeas-corpus ou habeas data, seja qual for a autoridade responsável pela ilegalidade ou abuso de poder.

A referida emenda foi justificada no sentido de que após a vigência do Ato Institucional $\mathrm{n}^{\circ}$ 5, durante o Regime Militar, várias garantias constitucionais haviam sido suspensas. Em razão disso, seria dever dos constituintes fortalecer e revigorar as garantias constitucionais, de forma a estendê-las à proteção de direitos coletivos e interesses difusos, e atribuir legitimidade processual ativa a sociedades e entidades representativas de seguimentos organizados na sociedade. Nesse sentido, o mandado de segurança, em conjunto com a ação popular, poderia assegurar a todos a proteção de seus direitos e interesses constitucionais.

A redação final do Anteprojeto da Subcomissão dos Direitos Políticos, dos Direitos Coletivos e Garantias restou da seguinte forma, consolidando a figura do mandado de segurança em um único dispositivo, tratando tanto de direitos individuais quanto de direitos coletivos (BRASIL, 1987, p. 15):

Art. 38. Conceder-se-á mandado de segurança para proteger direito individual ou coletivo, não amparado por "habeas corpus" ou "habeas data", seja o responsável pela ilegalidade ou abuso de poder pessoa física ou jurídica, de direito público ou privado.

No Anteprojeto do Relator da Subcomissão de Garantia da Constituição, Reforma e Emendas, Deputado Nelton Friedrich, também se inseriu previsão acerca do mandado de segurança coletivo. A ideia era a de atribuir legitimidade ativa a entidades, como os partidos políticos, porque possuiriam maior liberdade e independência para agir que os indivíduos que as integram. Além disso, o mandado de segurança coletivo era entendido como instrumento voltado a garantir o cumprimento da Constituição (BRASIL, 1987, p. 22; 32-33). A redação final do referido anteprojeto foi a seguinte (BRASIL, 1987, p. 9):

Art. 29 - O mandado de segurança coletivo, para proteger direito líquido e certo não amparado por "habeas corpus", pode ser impetrado por Partidos Políticos, organizações sindicais, órgãos fiscalizadores do exercício de profissão, associações de classe e associações legalmente constituídas e em funcionamento há, pelo menos, um ano, na defesa dos interesses de seus membros ou associados. 
Terminado o Anteprojeto da Subcomissão dos Direitos Políticos, dos Direitos Coletivos e Garantias, o texto passou a tramitar pela Comissão da Soberania e dos Direitos e Garantias do Homem e da Mulher. Iniciou-se, então, a Etapa 3 da ANC. O anteprojeto da Comissão manteve o texto do anteprojeto da Subcomissão (BRASIL, 1987, p. 24).

O Anteprojeto da Subcomissão de Garantia da Constituição, Reforma e Emendas, por sua vez, passou a tramitar na Comissão da Organização Eleitoral, Partidária e Garantia das Instituições. A redação foi mantida (BRASIL, 1987, p. 13).

Em seguida, iniciou-se a Etapa 4 da ANC, em que foi instituída a Comissão de Sistematização, a fim de conjugar os anteprojetos de todas as Comissões, para unificar o texto constitucional. No Anteprojeto da Comissão de Sistematização, relatado por Bernardo Cabral, manteve-se a redação que havia sido concebida pela Comissão da Organização Eleitoral, Partidária e Garantia das Instituições, prevendo o mandado de segurança coletivo como instrumento para a tutela de interesses de membros ou associados de partidos políticos, organizações sindicais, associações de classe e associações legalmente constituídas e em funcionamento há pelo menos um ano (BRASIL, 1987. p. 10):

Art. 36 - Conceder-se-á mandado de segurança para proteger direito líquido e certo, individual ou coletivo, não amparado por "habeas corpus" ou "habeas data", seja o responsável pela ilegalidade ou abuso de poder pessoa física ou jurídica, de direito público ou privado

Parágrafo único - o mandado de segurança coletivo, para proteger direito líquido e certo não amparado por "habeas corpus", pode ser impetrado por Partidos Políticos, organizações sindicais, associações de classe e associações legalmente constituídas em funcionamento há pelo menos um ano, na defesa dos interesses de seus membros ou associados.

O Projeto A da Constituição, resultado do término da deliberação da Comissão de Sistematização, que marcou o início da Etapa 5 da ANC, manteve a restrição de que o mandado de segurança coletivo poderia ser impetrado por partido político para a tutela de interesses dos seus membros ou associados (BRASIL, 1987, p. 8):

$\S 49$. Conceder-se-á mandado de segurança para proteger direito líquido e certo, individual ou coletivo, não amparado por "habeas-corpus" ou "habeas-data", seja qual for a autoridade responsável pela ilegalidade ou abuso de poder, estendendose a proteção contra a conduta de particulares no exercício de atribuições do Poder Público.

$\S 50$. O mandado de segurança coletivo pode ser impetrado por partido político, com representação na Câmara dos Deputados ou no Senado Federal, organização sindical, entidade de classe ou qualquer associação legalmente constituída, em funcionamento há pelo menos um ano, em defesa dos interesses de seus membros ou associados.

Apresentadas e deliberadas emendas no Plenário do Congresso Nacional, foi consolidado o Projeto B da Constituição, que previa, em seu art. $5^{\circ}$, inciso LXXI, a seguinte redação (BRASIL, 1987, p. 18):

LXX - conceder-se-á mandado de segurança para proteger direito líquido e certo, não amparado por "habeas-corpus" ou "habeas-data", seja o responsável pela ilegalidade ou abuso de poder autoridade pública ou agente de pessoa jurídica no 
exercício de atribuições do Poder Público;

LXXI - É assegurada a impetração de mandado de segurança coletivo, em defesa dos interesses de seus membros ou associados, por:

a) partido político com representação no Congresso Nacional;

b) organização sindical, entidade de classe ou associação legalmente constituída e em funcionamento há pelo menos um ano.

Observa-se que ambos os Projetos A e B da Constituição Federal de 1988 previam que tanto para os partidos políticos quanto para as organizações sindicais, entidades de classe e associações, o mandado de segurança coletivo somente seria cabível se fosse impetrado na defesa dos interesses de seus membros, filiados ou associados.

No entanto, não foi essa a redação final da Constituição Federal de 1988. Durante a análise das emendas oferecidas ao Projeto B surgiu a proposta de redação que veio a ser consolidada na redação final da Constituição. Basicamente, a redação atual do art. $5^{\circ}$, inciso LXX, é idêntica às emendas apresentadas por Fernando Henrique Cardoso e Raimundo Bezerra.

Fernando Henrique Cardoso (BRASIL, 1987, p. 202) requereu a transferência da expressão "em defesa dos interesses de seus membros ou associados", para o final apenas da alínea "b" do dispositivo constitucional, uma vez que a limitação de só poder agir em defesa de seus membros não se aplicaria ao partido político, conforme havia sido aprovado no primeiro turno da votação do Projeto B. No mesmo sentido a emenda sugerida por Raimundo Bezerra (BRASIL, 1987, p. 190).

A atual redação do art. $5^{\circ}$, inciso LXX, da Constituição já havia sido consolidada, portanto, no Projeto C (BRASIL, 1987, p. 9), resultado do segundo turno de votações no Plenário. O partido político, apesar da sua natureza associativa, não teve sua legitimidade para impetrar mandado de segurança coletivo expressamente restrita à defesa de seus filiados.

Em seguida, submetido o texto do projeto de Constituição à Comissão de Redação, dando início à Etapa 6 da ANC, não houve alteração do dispositivo pertinente ao mandado de segurança coletivo, tendo sido consolidado o Projeto D da Constituição, contendo a redação final (BRASIL, 1987, p. 9).

Foi promulgada (Etapa 7), então, a Constituição Federal de 1988, com a seguinte redação em seu art. $5^{\circ}$, inciso LXX:

Art. $5^{\circ} .[\ldots]$

LXX - o mandado de segurança coletivo pode ser impetrado por:

a) partido político com representação no Congresso Nacional;

b) organização sindical, entidade de classe ou associação legalmente constituída e em funcionamento há pelo menos um ano, em defesa dos interesses de seus membros ou associados;

Dessa análise da evolução dos debates acerca do mandado de segurança coletivo durante a Assembleia Nacional Constituinte de 1987, é possível chegar às seguintes conclusões:

i) o mandado de segurança coletivo foi disposto na Constituição a fim de ampliar, expressamente, a extensão do mandado de segurança, para tutelar os direitos ou interesses coletivos, próprios de uma sociedade de massa;

ii) o mandado de segurança coletivo não é uma espécie nova de mandado de segurança, mas o mesmo remédio constitucional, com a ampliação do seu objeto, possibilitando a tutela dos direitos ou interesses coletivos (em sentido amplo) (PASSOS, 1989, p. 7);

iii) houve extensa deliberação quanto à redação do dispositivo, sendo certo que, ao final, apenas para a alínea " $b$ " do inciso LXX do art. 5 da Constituição de 1988 foi 
mantida a expressão "em defesa dos interesses de seus membros ou associados”, não tendo sido feita essa restrição ao partido político porque a própria Assembleia Nacional Constituinte, deliberadamente, assim decidiu.

Além da compreensão acerca da função do mandado de segurança no sistema de acesso à justiça, cabe, em vista do rol de legitimados estabelecido no dispositivo constitucional, questionar se esse writ também desempenharia papel relevante na missão constitucionalmente atribuída aos partidos políticos.

\section{UMA VISÃO SOBRE O PAPEL INSTITUCIONAL DO PARTIDO POLÍTICO NA CONSTITUIÇÃO DE 1988}

O partido político é tratado de forma especial pela Constituição de 1988, inclusive em dispositivos próprios, no Capítulo V ("Dos partidos políticos") do Título II ("Dos direitos e garantias fundamentais"). Isso, certamente, decorreu da necessidade de se reafirmar princípios democráticos em uma nova configuração da organização do Estado e de sua relação com a sociedade, que marcou o processo constituinte e o advento da Constituição de 1988 (KLEIN, 2002, p. 93).

O partido político é elemento fundamental para a organização governamental no Brasil. Funciona como meio entre a sociedade e o Estado, no exercício do poder político. Nessa perspectiva, a Constituição Federal de 1988 prevê, em seu art. $1^{\circ}$, parágrafo único, que "todo o poder emana do povo, que o exerce por meio de representantes eleitos ou diretamente, nos termos desta Constituição".

A estruturação governamental no Brasil é baseada num regime de partidos. O exercício do poder político é feito, como regra, de forma representativa. No entanto, para que alguém possa se candidatar a algum mandato político eletivo no Brasil há a necessidade de que seja filiado a algum partido político (art. 14, $\S 3^{\circ}$, da Constituição Federal de 1988). A fíliação partidária é o elo político entre o filiado e o partido, sendo "verdadeiro laço ideológico de compromisso político" (AIETA, 2006, p. 246), o que torna necessário que o partido político seja fiel ao seu programa partidário e à finalidade partidária. De outro ponto de vista, concebendo-se o mandato como veículo de uma vontade coletiva (AIETA, 2006, p. 304-311), o candidato eleito também deve cumprir as normas relativas à fidelidade partidária, bem como o programa partidário, além do estatuto do partido político e outras diretrizes partidárias, a fim de atender a opinião política dos filiados e das pessoas que contribuíram para o êxito na empreitada eleitoral.

A Constituição é limite objetivo da representação política, que estabelece as condições para o exercício do mandato (DESIREE, 2012, p. 33-34). Sendo assim, as atribuições parlamentares transcendem os interesses do próprio partido político e dos eleitores, incluindo interesses da sociedade em geral.

O papel do partido político, no âmbito constitucional, no entanto, vai além da mera representação política. Um exemplo disso é o art. 74 , $\$ 2^{\circ}$, da Constituição Federal de 1988, que dispõe que o partido político é parte legítima para, na forma da lei, denunciar irregularidades perante o Tribunal de Contas da União. Observa-se que a Constituição prevê para o partido político função fiscalizatória, no que diz respeito aos aspectos contábil, financeiro, orçamentário, operacional e patrimonial dos entes da federação e das entidades da administração direta e indireta, no que diz respeito à legalidade, legitimidade, economicidade, aplicação de subvenções e renúncia de receitas (art. 70, caput, da Constituição Federal de 1988).

Ademais, o partido político deve prestar contas à Justiça Eleitoral, conforme dispõe o art. 17, inciso III, da Constituição Federal de 1988.

O partido político, desde que possua representação no Congresso Nacional, é também legitimado para a propositura de ações de controle concentrado de constitucionalidade, a fim de 
garantir a integridade da ordem constitucional, conforme dispõe o art. 103, inciso VIII, da Constituição Federal de 1988 (MENDES; BRANCO, 2014, p. 1392). Quanto a essa legitimação, o Supremo Tribunal Federal possui entendimento consolidado no sentido de que os partidos políticos não precisam demonstrar pertinência temática para a propositura de ação de controle concentrado de constitucionalidade, conforme restou consignado na ADI MC $\mathrm{n}^{\mathbf{0}} 1.096 / \mathrm{RS}$. Isso se deve à posição institucional do partido político na Constituição Federal de 1988, no sentido de que possui o poder-dever de zelar tanto pela preservação da supremacia normativa da Constituição quanto pela defesa da integridade jurídica do ordenamento constitucional, mediante a instauração de ação de controle concentrado de constitucionalidade.

Diversas são as concepções doutrinárias acerca dos partidos políticos. As concepções mais tradicionais os analisam do ponto de vista organizacional e funcional, e, portanto, os entendem como "máquinas eleitorais", isto é, como associações que se estruturam e se organizam para reunir eleitores em favor de seus candidatos (MEZZAROBA, 2003, p. 90), concebendo-os como instrumentos aptos a legitimar o exercício do poder político. Essa abordagem não considera os partidos políticos de uma perspectiva transformadora ou democratizadora (MEZZAROBA, 2003, p. 115) e essa dimensão também deve ser agregada à concepção de partido político abrangida na nossa realidade constitucional. Para Orides Mezzaroba (2003, p. 90), "os partidos aparecem, então, como instrumentos mediadores entre a Sociedade e o Estado, com a função de aglutinar vontades individuais e harmonizá-las em vontades coletivas".

A partir de uma primeira ótica, portanto, o partido político possui caráter associativo (BUZAID, 1992, p. 94) e o vínculo que une seus membros é, em princípio, de caráter pessoal (ideológico). Pode-se entender que o partido político é uma associação composta por uma fração da sociedade, que reúne pessoas que manifestam interesses políticos semelhantes ${ }^{4}$ (BOBBIO, MATTEUCCI e PASQUINO, 1998, p. 898-899). A natureza de sua ação volta-se, essencialmente, à conquista do poder político dentro de uma comunidade, contando com uma "multiplicidade de estímulos e motivações que levam a uma ação política associada à consecução de fins 'objetivos' e/ou "pessoais"":

[...] compreende formações sociais assaz diversas, desde os grupos unidos por vínculos pessoais e particularistas às organizações complexas de estilo burocrático e impessoal, cuja característica comum é a de se moverem na esfera do poder político.

No Brasil, a natureza jurídica do partido político é prevista pela própria Constituição Federal de 1988 no art. $17, \S 2^{\circ}$, ao dispor que "os partidos políticos, após adquirirem personalidade jurídica, na forma da lei civil, registrarão seus estatutos no Tribunal Superior Eleitoral. Nesse sentido, no âmbito infraconstitucional, o Código Civil de 2002, em seu art. 44, inciso V, dispõe que os partidos políticos são pessoas jurídicas de direito privado. No mesmo sentido o art. $1^{\circ}$ da Lei $n^{\circ} 9.096$, de $1995^{5}$. A necessidade de registro dos estatutos partidários no Tribunal Superior Eleitoral, após o partido político ter adquirido personalidade jurídica (art. 17, § $2^{\circ}$, da Constituição Federal de 1988) não lhe retira o caráter privado, mas funciona meramente como controle estatal (SILVA, 2005, p. 404) da conformidade de seus estatutos com a Constituição Federal.

Nessa perspectiva, a Lei $\mathrm{n}^{\circ}$ 9.096, de 1995, que regulamenta o disposto nos arts. 17 (liberdade partidária) e $14, \S 3^{\circ}$, inciso V (fidelidade partidária), da Constituição Federal de 1988,

\footnotetext{
${ }^{4}$ De acordo com Orides Mezzaroba (2003, p. 91), a etimologia da palavra "partido" encontra-se no latim e decorre do verbo partire, que significa dividir, parte, fração, pedaço, uma parte que compõe um todo.

${ }^{5} \mathrm{O}$ que assemelha os partidos políticos e as associações, portanto, é o fato de que ambos são pessoas jurídicas de direito privado que se constituem de pessoas com ideias ou interesses semelhantes, que se unem em prol de determinado objetivo (não econômico). O Enunciado n ${ }^{\circ} 142$ da III Jornada de Direito Civil do Conselho da Justiça Federal é nesse sentido: "os partidos políticos, os sindicatos e as associações religiosas possuem natureza associativa, aplicando-se-lhes o Código Civil” (BRASIL, 2004, p. 2).
}

Revista de Direito Brasileira | Florianópolis, SC | v. 23 | n. 9 | p. 63-82 |Mai./Ago. 2019 
prevê, em seu art. $1^{\circ}$, que "o partido político, pessoa jurídica de direito privado, destina-se a assegurar, no interesse do regime democrático, a autenticidade do sistema representativo e a defender os direitos fundamentais definidos na Constituição Federal".

Embora se trate de entidade associativa privada, a participação do partido político no governo torna-os instrumentos da prestação de serviços públicos (em sentido amplo) (SILVA, 2005, p. 403). Observa-se que o papel do partido político na ordem jurídica brasileira não se restringe ao atendimento dos interesses de seus filiados ou mesmo de seus eleitores.

Portanto, o ordenamento jurídico brasileiro e, em especial, a Constituição Federal de 1988 incumbiu o partido político de funções democratizadoras, não o vislumbrando apenas como máquinas eleitorais. Muito além disso, entendeu que o papel institucional do partido político abrange a defesa da integridade da própria ordem constitucional e dos direitos e garantias fundamentais, considerando-o elemento necessário para a estrutura social, democrática e política brasileira.

\section{OS ASPECTOS PROCESSUAIS DA CONTROVÉRSIA ACERCA DA LEGITIMIDADE DO PARTIDO POLÍTICO PARA IMPETRAR MANDADO DE SEGURANÇA COLETIVO}

Instituída expressamente a possibilidade de impetrar o mandado de segurança coletivo, a Constituição Federal de 1988 elegeu algumas entidades representativas da sociedade para comporem o rol de legitimados ativos: as organizações sindicais, as entidades de classe, as associações e os partidos políticos.

Costuma-se afirmar que o mandado de segurança coletivo não é ação constitucional nova, mas o próprio mandado de segurança já existente, cuja tutela foi expressamente ampliada para abarcar direitos ou interesses coletivos(PASSOS, 1989, p. 7). Portanto, as regras referentes aos requisitos para impetração do mandado de segurança individual são aplicáveis, no que couberem, ao mandado de segurança coletivo. Nesse mesmo sentido, Hermes Zaneti Jr. (2013, p. 67-69) e Marcelo Navarro Ribeiro Dantas (2000, p. 20-24).

Com isso, todos os requisitos constitucionais previstos expressamente para a impetração de mandado de segurança individual se aplicam ao mandado de segurança coletivo: direito líquido e certo, não amparado por habeas corpus ou habeas data, quando o responsável pela ilegalidade ou abuso de poder for autoridade pública ou agente de pessoa jurídica no exercício de atribuições do Poder Público.

No entanto, a Constituição Federal de 1988 prevê que o mandado de segurança coletivo pode ser impetrado por partido político com representação no Congresso Nacional (art. $5^{\circ}$, inciso LXX, alínea "a"), deixando de prever, nessa hipótese, como o fez para as associações e sindicatos (art. 5", inciso LXX, alínea "b"), restrição à defesa dos interesses de seus membros ou associados.

O Supremo Tribunal Federal e o Superior Tribunal de Justiça passaram a enfrentar, desde a entrada em vigor da Constituição Federal de 1988, os desafios que tangenciavam a utilização do mandado de segurança coletivo nos casos concretos.

O primeiro julgado de mandado de segurança coletivo impetrado por partido político em que houve ampla discussão acerca dos limites do objeto tutelado, no Superior Tribunal de Justiça, foi o MS no 197/DF, apreciado em 1990. Foi impetrado pelo Partido dos Trabalhadores - PT em face do Ministro de Estado da Previdência e Assistência Social, a fim de defender milhões de aposentados em questões previdenciárias.

No julgamento do MS no 197/DF, ficou consignado no voto vencido, do Relator, Ministro José de Jesus Filho, que a legitimidade do partido político para impetrar mandado de segurança coletivo deve ser examinada em seu campo político, de forma a considerar a legislação que cria e estrutura os partidos políticos. Sendo assim, uma vez que a Lei n ${ }^{0} 5.682$, de 1971, previa que os 
partidos políticos "destinam-se a assegurar, no interesse do regime democrático, a autenticidade do sistema representativo e a defender os direitos humanos fundamentais, definidos na Constituição", e que o texto constitucional exige a presença dos partidos políticos, um dos meios de fortalecê-los é possibilitar a tutela de interesses e direitos de determinados seguimentos sociais, sem representatividade ativa, cujo sucesso atrairá novos filiados ou, ao menos, simpatizantes. Sendo assim, concluiu o Ministro que "os partidos estão legitimados ativamente, por lei, a ingressar em juízo na defesa dos postulados que lhes cumpre preservar e defender".

No entanto, o voto do Ministro Garcia Vieira inaugurou a divergência, no sentido de que a Constituição Federal de 1988 autoriza o partido político a impetrar mandado de segurança coletivo apenas em defesa de seus filiados e em questões políticas, desde que autorizado por lei ou pelo estatuto, no que foi acompanhado pelo Ministro Américo Luz. Essa situação seria semelhante à hipótese em que a Constituição autoriza o sindicato a defender os direitos ou interesses coletivos ou individuais da categoria (art. $8^{\circ}$, inciso III).

O Ministro Vicente Cernicchiaro, por outro lado, entendeu que, não obstante o silêncio da Constituição Federal de 1988, a atuação dos partidos políticos não é própria para pugnar em juízo interesse setorial da sociedade (grupo determinado), exceto o de seus filiados. Com base em parecer do Ministério Público, que, por sua vez, faz referência à obra de Péricles Prade (1987, p. 43-46), o Ministro consignou em seu voto que os interesses coletivos, em sentido estrito, pressuporiam a reunião de pessoas vinculadas por um objetivo comum e diriam respeito, portanto, aos fins institucionais dos grupos (associações, partidos políticos, sindicatos), e resultariam do vínculo associativo, ou, com mais precisão, da affectiosocietatis, que liga os associados ou filiados aos fins da associação. Com isso, o partido político somente poderia defender os interesses de seus filiados (coletivo e individual homogêneo) e os interesses difusos. Estes porque é conferida ao partido político a função de defender interesses dirigidos a toda a sociedade.

O Ministro Carlos Mário Velloso, por outro lado, defendeu que o partido político somente poderia impetrar mandado de segurança para a defesa de direitos relativos à cidadania, isto é, direitos políticos, previstos nos arts. 14 a 16 da Constituição Federal de 1988, direitos referentes aos partidos políticos, previstos no art. 17, e outros direitos que digam respeito ao processo eleitoral. Ao final de seu voto, o Ministro consignou que não poderia "admitir, entretanto, que a Constituição tenha erigido o partido político como parte legítima para a defesa de todos os indivíduos, em todos os campos".

Observa-se que as dificuldades na aplicação do instituto já haviam sido postas e estavam sendo amplamente debatidas. Apenas nesse acórdão do Superior Tribunal de Justiça, quatro posicionamentos diferentes com relação aos limites da legitimidade ativa do partido político para impetrar mandado de segurança coletivo, quais sejam:

i) os partidos estão legitimados a defender os postulados que lhes cumpre preservar e defender, com base na Lei dos Partidos Políticos; ou

ii) os partidos políticos ostentam legitimidade para impetrar mandado de segurança coletivo apenas em defesa de seus filiados e em questões políticas; ou

iii) os partidos políticos podem defender os direitos ou interesses difusos, mas quanto aos direitos ou interesses coletivos e individuais homogêneos (direitos ou interesses setoriais) somente poderiam defender os que forem de seus filiados; ou

iv) os partidos políticos podem defender os direitos políticos, direitos referentes aos partidos políticos e outros direitos que digam respeito ao processo eleitoral.

Ao final, nesse julgamento, prevaleceu, por maioria, a tese da ilegitimidade do partido político para impetrar o mandado de segurança. Venceu a tese de que os partidos políticos não têm legitimidade para impetrar mandado de segurança coletivo para a defesa de direitos ou interesses coletivos que não fossem os de seus filiados (no que se referisse aos fins partidários).

No Supremo Tribunal Federal, no julgamento do RE no 196.184/AM, em 2004, discutiuse, também, os limites da legitimidade ativa do partido político no mandado de segurança coletivo. 
Trata-se de mandado de segurança coletivo impetrado pelo Partido Socialista Brasileiro - PSB, a fim de impugnar o Decreto nº 975, de 1991, do Município de Manaus, que resultava na majoração de tributo.

No caso, a Relatora, Ministra Ellen Gracie, entendeu que a Constituição não previu limitações materiais à impetração de mandado de segurança coletivo por partido político. Isso porque a Constituição dividiu os legitimados para a impetração do mandado de segurança coletivo em duas alíneas, e somente quanto à legitimidade das associações, entidades de classe e organizações sindicais restringiu à defesa dos interesses de seus membros ou associados, e, portanto, não quis criar essa restrição aos partidos políticos. Ademais, entendeu a Ministra que o partido político poderia defender todos os interesses difusos e coletivos que afetem a sociedade, considerando que no controle abstrato de constitucionalidade o Supremo Tribunal Federal (ADI MC n $\left.{ }^{\circ} 1.096 / \mathrm{RS}\right)$ já decidiu que o requisito da "pertinência temática" não é exigido dos partidos políticos.

No entanto, no caso concreto, entendeu tratar-se de direitos individualizáveis e divisíveis dos contribuintes, e que, portanto, o partido político não teria legitimidade para impetrar mandado de segurança coletivo para tutelá-los. O Ministro Carlos Britto acompanhou a relatora.

O Ministro Gilmar Mendes não acompanhou a relatora quanto à legitimidade universal que teria o partido político para a defesa de interesses aparentemente universais. Entendeu que o partido político só poderia defender os interesses de seus filiados. Acompanhou-a, contudo, quanto à impossibilidade de tutela dos contribuintes no caso concreto. $\mathrm{O}$ voto foi acompanhado pelo Ministro Cézar Peluso.

O Ministro Marco Aurélio entendeu que a impetração de mandado de segurança coletivo por partido político seria mesmo universal, e abrangeria, também, interesses individuais homogêneos, uma vez que a Constituinte não previu restrições. O Ministro partiu, no entanto, de um ponto de vista também pragmático, ao referir-se à ausência de defensorias públicas constituídas regularmente nos Estados e à ausência de condições para que os indivíduos economicamente hipossuficientes contratassem um advogado sem prejuízo ao próprio sustento.

Já o Ministro Carlos Velloso manteve o mesmo entendimento adotado quando era Ministro do Superior Tribunal de Justiça (no MS no 197/DF), no sentido de que o partido político somente poderia impetrar mandado de segurança coletivo em favor de seus filiados, especificamente no que diz respeito a questões de direitos políticos e direitos fundamentais. No entanto, no que diz respeito às organizações sindicais, entidades de classe e associações, o Ministro entendeu ser possível, em nome de seus associados, impetrar mandado de segurança que tenha por objeto tributo, considerando que a alínea "b" do inciso LXX do art. 5 da Constituição de 1988 teria mais amplitude que a alínea "a" do inciso LXX do mesmo artigo.

Por fim, o Ministro Sepúlveda Pertence, no que foi acompanhado pelo Ministro Nelson Jobim, ressaltou que não possuía entendimento firmado quando à extensão da legitimidade dada ao partido político, mas que o mandado de segurança coletivo deveria ser utilizado para a proteção de direito subjetivo líquido e certo, não sendo possível, por exemplo, a tutela de interesses difusos. Acompanharam a relatora no sentido de que os interesses individuais, patrimoniais, não podem ser tutelados. O Ministro Nelson Jobim acompanhou o voto, mencionou que o partido político não seria representativo da sociedade, mas apenas de parte dela, e deixou claro que examinaria o tema em outro momento com mais atenção.

Sendo assim, venceu a tese de que no caso da tutela de direitos ou interesses individuais homogêneos relativos à majoração de tributo o partido político não possuiria legitimidade ativa para impetrar mandado de segurança coletivo.

Somente nesse acórdão do Supremo Tribunal Federal, conforme exposto, cinco posicionamentos diferentes foram manifestados pelos Ministros.

O posicionamento tanto do Superior Tribunal de Justiça quanto do Supremo Tribunal Federal se mostrou, portanto, restritivo. É possível constatar em ambos os Tribunais que os 
posicionamentos dos Ministros quanto ao tema foram extremamente diversificados. Não se chegou, na jurisprudência, a uma orientação segura quanto aos limites da legitimidade do partido político para impetrar mandado de segurança coletivo.

Em síntese, observa-se que duas questões se mostraram controvertidas na jurisprudência do Superior Tribunal de Justiça e na do Supremo Tribunal Federal: i) quais são os limites objetivos do mandado de segurança coletivo impetrado por partido político?; e ii) quais são os limites subjetivos do mandado de segurança coletivo impetrado por partido político?

No entanto, apesar dessa controvérsia, foi a jurisprudência do Superior Tribunal de Justiça que inspirou a edição do Projeto de Lei no 5.067, de 2001, enviado ao Congresso Nacional pela Presidência da República por meio da Mensagem no 824 de 2001 (DIREITO, 2003, p. 305-309).

O Projeto de Lei $n^{\circ} 5.067$, de 2001, resultou na Lei $n^{\circ} 12.016$, de 2009, que regulamenta o mandado de segurança individual e coletivo, a qual, em seu art. 21, caput e parágrafo único, dispõe que:

Art. 21. O mandado de segurança coletivo pode ser impetrado por partido político com representação no Congresso Nacional, na defesa de seus interesses legítimos relativos a seus integrantes ou à finalidade partidária [...]

Parágrafo único. Os direitos protegidos pelo mandado de segurança coletivo podem ser:

I - coletivos, assim entendidos, para efeito desta Lei, os transindividuais, de natureza indivisível, de que seja titular grupo ou categoria de pessoas ligadas entre si ou com a parte contrária por uma relação jurídica básica;

II - individuais homogêneos, assim entendidos, para efeito desta Lei, os decorrentes de origem comum e da atividade ou situação específica da totalidade ou de parte dos associados ou membros do impetrante.

Esse posicionamento restritivo retirou do mandado de segurança coletivo o seu potencial de ser um dos meios para que o partido político pudesse atender à missão institucional que lhe atribuiu a Constituição Federal, cabendo questionar se o tema merece ser revisitado no contexto constitucional atual.

\section{UMA VISÃO CRÍTICA SOBRE A LEGITIMIDADE DOS PARTIDOS POLÍTICOS PARA IMPETRAR MANDADO DE SEGURANÇA COLETIVO, NO REGIME DA LEI No 12.016, DE 2009}

A Lei $\mathrm{n}^{\circ}$ 12.016, de 2009, ao prever nos incisos de seu parágrafo único os conceitos de direitos coletivos e de direitos individuais homogêneos, aproveitou-se, por certo, dos parâmetros estabelecidos pelo Código de Proteção e Defesa do Consumidor (CDC). O CDC (Lei nº 8.078, de 1990) atua como verdadeira norma de orientação do microssistema de tutela dos direitos ou interesses coletivos.

O art. 81, parágrafo único, inciso I, do Código de Proteção e Defesa do Consumidor, conceitua os direitos ou interesses difusos (não previstos expressamente no art. 21, parágrafo único, da Lei $n^{\circ} 12.016$, de 2009) ao dispor que são "os transindividuais, de natureza indivisível, de que sejam titulares pessoas indeterminadas e ligadas por circunstâncias de fato". Nesse sentido, no que diz respeito à titularidade dos direitos ou interesses difusos, o que os distingue é a sua indeterminabilidade no plano individual, sendo que a violação a eles atinge toda a comunidade ou determinadas coletividades cujos titulares são indefinidos. Essa indeterminabilidade caracteriza os direitos ou interesses difusos no aspecto subjetivo. Quanto ao aspecto objetivo, os direitos ou interesses difusos são indivisíveis em razão de sua própria natureza, não se tratando de 
“justaposição de litígios menores” (MOREIRA, 1991, p. 1).

De outro lado, os direitos ou interesses coletivos em sentido estrito foram conceituados pelo Código de Proteção e Defesa do Consumidor, em seu art. 81, parágrafo único, inciso II (reproduzido no inciso I do parágrafo único do art. 21 da Lei $\mathrm{n}^{\circ} 12.016$, de 2009) como sendo os "transindividuais, de natureza indivisível de que seja titular grupo, categoria ou classe de pessoas ligadas entre si ou com a parte contrária por uma relação jurídica base". Os direitos ou interesses coletivos dizem respeito, portanto, a grupo, categoria ou classe de pessoas determinadas ou determináveis, ligadas pela mesma relação jurídica básica. No entanto, o objeto é indivisível, isto é, não individualizável, pois o direito ou interesse pertence ao grupo ou categoria, considerado como um todo.

Já os direitos individuais homogêneos são, nos termos do art. 81, parágrafo único, inciso I, do Código de Proteção e Defesa do Consumidor, "os decorrentes de origem comum”. Tal origem comum, para o mandado de segurança coletivo, de acordo com o inciso II do parágrafo único do art. 21 da Lei $n^{\text {o }}$ 12.016, de 2009, decorre "da atividade ou situação específica da totalidade ou de parte dos associados ou membros do impetrante". Aqui, o objeto da pretensão é divisível (é individualizável a parcela que pertence a cada sujeito integrante do grupo). Os titulares são, portanto, determinados ou determináveis. Nos direitos individuais homogêneos a relação jurídica é questionada apenas como causa de pedir, uma vez que se originam de circunstâncias de fato comuns. Portanto, a "medida do direito" de cada indivíduo pode ser diversa (MAZZILI, 2007, p. $54)^{6}$.

Como dito, a essa forma de ver o direito processual coletivo que a Lei no 12.016, de 2009, prestou homenagens quando utilizou como fator de discriminação para fixar a abrangência dos interesses tutelados no mandado de segurança coletivo impetrado por partido político, as categorias estabelecidas no art. 81, parágrafo único, do CDC. Com base nessas categorias legais, a Lei $\mathrm{n}^{\circ}$ 12.016, de 2009, estabeleceu expressamente dois limites: a) a defesa apenas de seus interesses legítimos relativos a seus integrantes ou à finalidade partidária; b) a proteção de direitos ou interesses coletivos e individuais homogêneos, excluída a proteção aos direitos ou interesses difusos.

Ao conferir ao partido político a possibilidade de defender direitos coletivos em sentido estrito e individuais homogêneos relativos a seus filiados, a Lei $n^{\circ} 12.016$, de 2009, concebe o partido político como entidade associativa. Nesse sentido também entendem Márcio Flávio Mafra Leal (2014, p. 278) e Teori Albino Zavascki (2017, p. 202). Trata-se, a rigor, de previsão ociosa, dado que a própria Constituição já confere aos partidos políticos legitimidade para tanto, no art. $5^{\circ}$, incisos XXI e LXX.

Deve-se destacar, no entanto, que a Lei n⿳0 12.016, de 2009, não restringe o cabimento do mandado de segurança coletivo apenas para a tutela dos interesses de seus filiados. $\mathrm{O}$ mandado de segurança coletivo também pode ser impetrado pelo partido político para a tutela de interesses outros, desde que relativos à finalidade partidária.

A finalidade partidária, conforme já exposto, encontra previsão legal, genérica, no art. $1^{\circ}$ da Lei n ${ }^{\circ}$ 9.096, de 1995: assegurar, no interesse do regime democrático, a autenticidade do sistema representativo e defender os direitos fundamentais. É certo que também o estatuto do partido político exerce papel fundamental na definição da finalidade partidária, ao prever de forma específica os objetivos de cada partido político.

Nesse cenário, surge a indagação: não havendo limitação constitucional e havendo previsão legal a respeito da possibilidade de o partido atuar na defesa de sua finalidade partidária,

\footnotetext{
${ }^{6}$ Diferentemente dos direitos ou interesses difusos, os direitos ou interesses coletivos em sentido estrito e os direitos ou interesses individuais homogêneos possuem como característica a determinabilidade do grupo titular do direito. O objeto do direito ou interesse coletivo em sentido estrito é, no entanto, indivisível, não sendo possível identificar a "medida do direito" de cada indivíduo, o que o diferencia do direito ou interesse individual homogêneo, que possui objeto divisível.
} 
o que obsta que o partido político impetre mandado de segurança coletivo com o fim de tutelar direitos coletivos e individuais homogêneos relativos a pessoas que não sejam os seus filiados, desde que, no entanto, relativos à finalidade partidária?

A correta leitura da Lei $n^{\circ} 12.016$, de 2009, deve levar em conta que o partido político é mais do que uma associação, dada sua função e missão institucional atribuída pela Constituição Federal de 1988 e pela Lei n $^{\circ}$ 9.096, de 1995, de modo que não se pode retirar a sua legitimidade para defender em juízo os valores e objetivos previstos no ordenamento jurídico e em seus estatutos, com todos os instrumentos processuais disponíveis.

Essa constatação faz surgir discussão sobre a possibilidade de tutela de direitos difusos por meio do mandado de segurança coletivo, dado que a Lei $n^{\circ} 12.016$, de 2009, não prevê expressamente essa faculdade (somente se referindo, como visto, à tutela de direitos coletivos em sentido estrito e de direitos individuais homogêneos). Trata-se aqui de questão também controvertida.

Antes do advento da Lei 12.016, de 2009, o Superior Tribunal de Justiça, no RMS no 10.131/PR (julgado em 2000), entendeu ser cabível a tutela de direitos difusos mediante mandado de segurança coletivo (diferentemente do posicionamento que restou vencedor no MS no 197/DF). No Supremo Tribunal Federal não foi encontrado julgado colegiado nesse mesmo sentido ${ }^{7} \mathrm{Na}$ doutrina, há corrente que adota o entendimento de que a tutela de direitos ou interesses coletivos mediante mandado de segurança coletiva é ampla, o que inclui a possibilidade de defesa de direitos ou interesses difusos, direitos ou interesses coletivos (em sentido estrito) e direitos ou interesses individuais homogêneos (DANTAS, 2000, p. 84; ZANETI JR., 2013, p. 70; LEAL, 2014, p. 277 278; ZAVASCKI, 2017, p. 200).

De forma diversa, Vicente Greco Filho (2010, p. 57) entende que a Lei do Mandado de Segurança (Lei no 12.016, de 2009) exclui os direitos ou interesses difusos do rol de proteção (uma vez que o art. 21, parágrafo único da Lei prevê apenas a tutela de direitos coletivos e individuais homogêneos) porque seriam mais interesses do que direitos, sendo, portanto, incompatíveis com o conceito de direito líquido e certo. Em sentido convergente, pela inviabilidade da tutela de direitos difusos por meio do mandado de segurança coletivo: Hely Lopes Meirelles, Arnoldo Wald e Gilmar Ferreira Mendes (2009, p. 36 e 123-124), Ernane Fidélis dos Santos (1990, p. 132) e José Rogério Cruz e Tucci (1990, p. 39-41).

Será válida a distinção entre interesse e direito, para fins de definição da abrangência do mandado de segurança coletivo? Entende-se que não.

Deve-se partir do pressuposto de que os requisitos constitucionais previstos expressamente para impetrar mandado de segurança individual se aplicam ao mandado de segurança coletivo: direito líquido e certo não amparado por habeas corpus ou habeas data, quando o responsável pela ilegalidade ou abuso de poder for autoridade pública ou agente de pessoa jurídica no exercício de atribuições do Poder Público (PASSOS, 1989, p. 7). O que muda é, portanto, a legitimidade ativa ${ }^{8}$.

Quando a Lei do Mandado de Segurança trata de "interesse", a referência processual

\footnotetext{
${ }^{7}$ No entanto, no Supremo Tribunal Federal, o Ministro Gilmar Mendes, Relator do MS no 34.070/DF, mandado de segurança coletivo impetrado pelo Partido Popular Socialista - PPS contra ato praticado pela ex-Presidente da República Dilma Rousseff, concernente à nomeação do ex-Presidente da República Luiz Inácio Lula da Silva ao cargo de Ministro Chefe da Casa Civil, deferiu liminar adotando posicionamento ampliativo da legitimidade ativa do partido político no mandado de segurança coletivo. Entendeu o Ministro que o partido político poderia impetrar mandado de segurança coletivo na defesa de interesses difusos. No entanto, esse julgado não chegou a ser discutido em Plenário. ${ }^{8} \mathrm{O}$ Enunciado $\mathrm{n}^{\circ} 101$ da Súmula da Jurisprudência do Supremo Tribunal Federal, aprovado na sessão plenária de 13/12/1963, no sentido de que "o mandado de segurança não substitui a ação popular", não deve ser aplicado ao mandado de segurança coletivo. Isso porque esse entendimento se consolidou anteriormente à Constituição Federal de 1988, em época na qual o ordenamento jurídico não previa, ao menos não expressamente, a possibilidade de tutela de direitos ou interesses coletivos por meio de mandado de segurança, mediante legitimação extraordinária. Não há falar, por conseguinte, na aplicação desse entendimento jurisprudencial ao mandado de segurança coletivo.
} 
relevante é a ideia de pretensão. Esclarece, a respeito, J. J. Calmon de Passos (1989, p. 10-11) que:

[...] um sujeito, portador de determinado interesse, dispõe, na ordem jurídica, de algum instrumento mediante cuja utilização ele pode ter, impositivamente, satisfeito seu interesse, com a submissão (coercitiva) da vontade do sujeito obrigado, aquele interesse necessariamente se reveste da natureza de um direito [...] e nem por serem transindividuais ou coletivos, ou sociais, esses interesses deixam de ser conteúdo de direitos, inclusive em sua dimensão subjetiva.

A redação do próprio art. 5, inciso LXX, alínea "b”, da Constituição Federal de 1988, parece ter sido elaborada nesse sentido, prevendo a tutela de "interesses". No art. $8^{\circ}$, inciso III, da Constituição Federal de 1988, também há a menção ao termo "interesse", conferindo ao sindicato a defesa dos direitos e interesses coletivos ou individuais da categoria. No mesmo sentido o art. 129, incisos III e V, da Constituição Federal de 1988, que prevê como função institucional do Ministério Público a proteção do patrimônio público e social, do meio ambiente e de outros interesses difusos e coletivos, bem como a defesa judicial dos direitos e interesses das populações indígenas.

A categoria processual "interesse" deve ser dissociada do conceito de "direito líquido e certo", o qual, como elegantemente definido por Celso Agrícola Barbi (2009, p. 53):

[...] é tipicamente processual, pois atende ao modo de ser de um direito subjetivo no processo: a circunstância de um determinado direito subjetivo realmente existir não lhe dá a caracterização de liquidez e certeza; esta só lhe é atribuída se os fatos em que se fundar puderem ser provados de forma incontestável, certa, no processo. E isso normalmente só ocorre quando a prova for documental, pois esta é adequada a uma demonstração imediata e segura dos fatos ${ }^{9}$.

Não deve prosperar, portanto, o entendimento doutrinário de Vicente Greco Filho (2010, p. 57), no sentido de que a tutela de direitos ou interesses difusos por meio do mandado de segurança coletivo seria incompatível com o conceito de direito líquido e certo. Isso porque é irrelevante a complexidade do direito que incidirá sobre os fatos comprovados documentalmente no mandado de segurança. Delimitados os fatos, cabe ao magistrado aferir a incidência de norma jurídica. Basta que ao impetrar o mandado de segurança coletivo, o partido político apresente provas documentais pré-constituídas que delimitem os fatos sobre os quais o juiz irá aplicar o direito.

Também não merece prosperar o entendimento de José Rogério Cruz e Tucci (1990, p. 39-41), de Hely Lopes Meirelles, Arnoldo Wald e Gilmar Ferreira Mendes (2009, p. 36 e 123-124), e de Ernane Fidélis dos Santos (1990, p. 132) no sentido de não ser possível a tutela de direitos difusos por meio do mandado de segurança coletivo, não havendo incompatibilidade com o instituto processual do mandado de segurança.

\footnotetext{
${ }^{9}$ Ernane Fidélis dos Santos (2011, p. 290-291) conceitua direito líquido e certo como todo aquele que pode ser reconhecido pela apreciação do modelo jurídico próprio com o fato nele adequado, sem necessidade de se socorrer de provas, ou quando muito somente da documental induvidosa, onde se resume e se esgota toda a indagação probatória do fato. Se a questão depender de outras provas, as vias ordinárias são o caminho específico. Nesse sentido, portanto, o direito líquido e certo é, basicamente, aquele delimitado em sua existência, pronto para ser exercido, sem que haja a necessidade de dilação probatória, podendo ser demonstrado mediante prova documental pré-constituída. Em outras palavras, é o direito apoiado em fatos incontroversos, demonstrados mediante prova documental pré-constituída. Tendo em vista os fatos incontroversos postos nos autos, caberá ao juiz solucionar a questão de direito (independentemente de sua complexidade). Nota-se que se trata de um conceito processual, que não tem relação de dependência com o direito material a ser tutelado.
} 


\section{CONCLUSÃO}

O cabimento do mandado de segurança coletivo impetrado por partidos políticos para tutelar direitos ou interesses coletivos em sentido amplo (incluindo, portanto, direitos ou interesses difusos) se justifica por diversas razões:

i) pelo aspecto histórico, uma vez que o constituinte não quis restringir ao partido político a tutela dos interesses de seus filiados;

ii) pela função institucional atribuída ao partido político, tanto em âmbito constitucional quanto infraconstitucional;

iii) pelo ponto de vista conceitual, a inexistência de incompatibilidade do conceito de direito líquido e certo com a noção de direitos ou interesses difusos;

iv) pelo sentido normativo que deve ser conferido ao microssistema de tutela de interesses coletivos, que visa, principalmente, a ampliar o acesso à justiça e a efetivar o direito material, sendo que, nesse sentido, não se identificam razões jurídicas para a restrição da proteção de direitos ou interesses difusos por meio do mandado de segurança coletivo impetrado por partido político.

O que, afinal, é relevante para compreender a amplitude da legitimidade dos partidos políticos na impetração de mandado de segurança coletivo é a finalidade partidária, estabelecida na Constituição, na legislação e nos estatutos, cabendo ampliar as opções para que o partido cumpra a sua missão institucional.

Faria sentido atribuir ao partido político menos prerrogativas e faculdades processuais que as associações, sendo que aqueles também possuem caráter associativo? Entende-se que não.

Nesse sentido, deve ser afastada, porque incompatível com a Constituição, a leitura de que a Lei n ${ }^{\circ} 12.016$, de 2009, em seu art. 21, caput e parágrafo único, restringe o cabimento do mandado de segurança coletivo quando impetrado por partido político apenas à tutela de direitos ou interesses coletivos em sentido estrito e individuais homogêneos, sendo possível também a tutela de direitos difusos, desde que relativos à finalidade partidária.

\section{REFERÊNCIAS}

AIETA, Vânia Siciliano. Partidos Políticos: Estudos em Homenagem ao Prof. Siqueira Castro. Tomo IV: atualizado até a EC 52/2006. Rio de Janeiro: Lumen Juris, 2006.

BARBI, Celso Agrícola. Do Mandado de Segurança. 12. ed. rev. e atual. por Bernardo Pimentel Souza. Rio de Janeiro: Forense, 2009.

BOBBIO, Norberto; MATTEUCCI, Nicola; PASQUINO, Gianfranco. Dicionário de Política. vol. 1. 11. ed. Trad. Carmen C. Varriale et al.; coord. trad. João Ferreira. Brasília: Editora Universidade de Brasília, 1998.

BRASIL. Anais da Assembleia Nacional Constituinte. 1987. Anteprojeto da Comissão da Organização Eleitoral, Partidária e Garantia das Instituições. Disponível em: http://www.camara.gov.br/internet/constituicao20anos/DocumentosAvulsos/vol-126.pdf. Acesso em 5 nov. 2016.

BRASIL. Anais da Assembleia Nacional Constituinte. 1987. Anteprojeto da Comissão da Soberania e dos Direitos e Garantias do Homem e da Mulher. Disponível em: http://www.camara.gov.br/internet/constituicao20anos/DocumentosAvulsos/vol-69.pdf. Acesso 
em 5 nov. 2016.

BRASIL. Anais da Assembleia Nacional Constituinte. 1987. Anteprojeto da Comissão de Sistematização. Disponível em:

http://www.camara.gov.br/internet/constituicao20anos/DocumentosAvulsos/vol-219.pdf. Acesso em 5 nov. 2016.

BRASIL. Anais da Assembleia Nacional Constituinte. 1987. Anteprojeto do Relator da Subcomissão de Garantia da Constituição, Reforma e Emendas. Disponível em:

http://www.camara.gov.br/internet/constituicao20anos/DocumentosAvulsos/vol-137.pdf. Acesso em 5 nov. 2016.

BRASIL. Anais da Assembleia Nacional Constituinte. 1987. Anteprojeto do Relator da Subcomissão dos Direitos Políticos, dos Direitos Coletivos e Garantias. Disponível em: http://www2.camara.leg.br/atividade-

legislativa/legislacao/Constituicoes_Brasileiras/constituicao-cidada/o-processoconstituinte/panorama-do-funcionamento/subcomissoes-tematicas/vol74.pdf. Acesso em 5 nov. 2016.

BRASIL. Anais da Assembleia Nacional Constituinte. 1987. Anteprojeto da Subcomissão de Garantia da Constituição, Reforma e Emendas. Disponível em:

http://www.camara.gov.br/internet/constituicao20anos/DocumentosAvulsos/vol-140.pdf. Acesso em 5 nov. 2016.

BRASIL. Anais da Assembleia Nacional Constituinte. 1987. Anteprojeto da Subcomissão dos Direitos Políticos, dos Direitos Coletivos e Garantias. Disponível em:

http://www.camara.gov.br/internet/constituicao20anos/DocumentosAvulsos/vol-77.pdf. Acesso em 5 nov. 2016.

BRASIL. Anais da Assembleia Nacional Constituinte. 1987. Emenda ao Anteprojeto do Relator da Subcomissão dos Direitos Políticos, dos Direitos Coletivos e Garantias. Disponível em: http://www.camara.gov.br/internet/constituicao20anos/DocumentosAvulsos/vol-75.pdf. Acesso em 5 nov. 2016.

BRASIL. Anais da Assembleia Nacional Constituinte. 1987. Emendas ao Projeto B da Constituição. Disponível em:

http://www.camara.gov.br/internet/constituicao20anos/DocumentosAvulsos/vol-301.pdf. Acesso em 5 nov. 2016.

BRASIL. Anais da Assembleia Nacional Constituinte. 1987. Projeto A da Constituição. Disponível em: http://www.camara.gov.br/internet/constituicao20anos/DocumentosAvulsos/vol251.pdf. Acesso em 5 mai. 2018.

BRASIL. Anais da Assembleia Nacional Constituinte. 1987. Projeto B da Constituição. Disponível em: http://www.camara.gov.br/internet/constituicao20anos/DocumentosAvulsos/vol299-sup01.pdf. Acesso em 5 nov. 2016.

BRASIL. Anais da Assembleia Nacional Constituinte. 1987. Projeto C da Constituição. Disponível em: http://www.camara.gov.br/internet/constituicao20anos/DocumentosAvulsos/vol314.pdf. Acesso em 5 nov. 2016. 
BRASIL. Anais da Assembleia Nacional Constituinte. 1987. Projeto D da Constituição. Disponível em: http://www.camara.gov.br/internet/constituicao20anos/DocumentosAvulsos/vol316.pdf. Acesso em 5 nov. 2016.

BRASIL. Conselho da Justiça Federal. Enunciados Aprovados - III Jornada de Direito Civil. 2004. Disponível em: http://daleth.cjf.jus.br/revista/enunciados/IIIJornada.pdf. Acesso em: 10 nov. 2016.

BRASIL. Constituição da República Federativa do Brasil de 1988. Disponível em: http://www.planalto.gov.br/ccivil_03/constituicao/constituicaocompilado.htm. Acesso em: 10 nov. 2016.

BRASIL. Lei $n^{\circ}$ 5.869, de 11 de janeiro de 1973. Disponível em: http://www.planalto.gov.br/ccivil_03/leis/L5869.htm. Acesso em: 10 nov. 2016.

BRASIL. Lei $n^{\circ} 8.078$, de 11 de setembro de 1990. Disponível em: http://www.planalto.gov.br/ccivil_03/Leis/L8078.htm. Acesso em: 10 nov. 2016.

BRASIL. Lei $n^{\circ}$ 9.096, de 19 de setembro de 1995. Disponível em: https://www.planalto.gov.br/ccivil_03/Leis/L9096.htm. Acesso em: 10 nov. 2016.

BRASIL. Lei $n^{o}$ 10.406, de 10 de janeiro de 2002 (Código Civil). Disponível em: http://www.planalto.gov.br/ccivil_03/leis/2002/L10406.htm. Acesso em: 10 nov. 2016.

BRASIL. Lei $n^{\circ} 12.016$, de 7 de agosto de 2009. Disponível em: http://www.planalto.gov.br/ccivil_03/_ato2007-2010/2009/lei/112016.htm. Acesso em: 10 nov. 2016.

BRASIL. Superior Tribunal de Justiça. Mandado de Segurança no 197/DF, Relator p/ acórdão: Ministro Garcia Vieira. Rel. original: Ministro José de Jesus. DJ, 8 mai. 1990. Publicado no Diário da Justiça de 20 ago. 1990. p. 7950. RSTJ vol. 12 p. 215. Disponível em: http://stj.jusbrasil.com.br/jurisprudencia/597983/mandado-de-seguranca-ms-197-df-19890009631-1. Acesso em: 5 nov. 2016.

BRASIL. Superior Tribunal de Justiça. Recurso em Mandado de Segurança $n^{\circ}$ 10.131/PR, Relator: Ministro Francisco Peçanha Martins. DJ, 18 fev. 2002. Publicado no Diário da Justiça de 18 fev. 2002. Disponível em: https://ww2.stj.jus.br/processo/revista/documento/mediado/?componente=IMG\&sequencial=313 53\&num_registro=199800627600\&data=20020218\&formato=PDF. Acesso em: 5 abr. 2018.

BRASIL. Supremo Tribunal Federal. Mandado de Segurança $n^{\circ}$ 34.070/DF. Relator: Ministro Gilmar Mendes. Publicado no Diário da Justiça Eletrônico de 22 mar. 2016. Disponível em: http://www.stf.jus.br/portal/processo/verProcessoPeca.asp?id=308995627\&tipoApp=.pdf. Acesso em: 5 nov. 2016.

BRASIL. Supremo Tribunal Federal. Medida Cautelar na Ação Direta de Inconstitucionalidade $n^{o}$ 1.096/RS. Relator: Ministro Menezes Direito. DJ, 16 mar. 1995. Publicado no Diário da Justiça de 4 abr. 1995. Disponível em: http://redir.stf.jus.br/paginadorpub/paginador.jsp?docTP=AC\&docID=346820. Acesso em: 5 
nov. 2016.

BRASIL. Supremo Tribunal Federal. Recurso Extraordinário $n^{\circ}$ 196.184/AM. Relatora: Ministra Ellen Gracie. DJ, 27 out. 2004. Publicado no Diário da Justiça de 18 fev. 2005. Disponível em: http://redir.stf.jus.br/paginadorpub/paginador.jsp?docTP=AC\&docID=234964. Acesso em: 5 nov. 2016.

BRASIL. Supremo Tribunal Federal. Súmula 101. Aprovada na Sessão Plenária de 13 dez. 1963. Disponível em:

http://www.stf.jus.br/arquivo/cms/jurisprudenciaSumula/anexo/Enunciados_Sumulas_STF_1_a_ 736_Completo.pdf. Acesso em: 5 mai. 2018.

BUZAID, Alfredo. Considerações sobre o mandado de segurança coletivo. São Paulo: Saraiva, 1992.

CAPPELlETTI, Mauro; GARTH, Bryant. Acesso à Justiça. Tradução Ellen Gracie Northfleet. Porto Alegre: Sergio Antonio Fabris Editor, 1988.

DANTAS, Marcelo Navarro Ribeiro. Mandado de Segurança Coletivo: Legitimação Ativa. São Paulo: Saraiva, 2000.

DIDIER JR., Fredie; ZANETI JR., Hermes. Curso de Direito Processual Civil: Processo Coletivo. Vol. 4. 7. ed. Salvador: JusPodivm, 2012.

DIREITO, Carlos Alberto Menezes. Manual do Mandado de Segurança. 4. ed. ampliada e atual. Rio de Janeiro: Renovar, 2003.

GRECO FILHO, Vicente. O Novo Mandado de Segurança: Comentários à Lei n. 12.016, de 7 de agosto de 2009. São Paulo: Saraiva, 2010.

KLEIN, Antônio Carlos. A Importância dos Partidos Políticos no Funcionamento do Estado. Brasília: Brasília Jurídica, 2002.

LEAL, Márcio Flávio Mafra. Ações coletivas. São Paulo: Revista dos Tribunais, 2014.

MAZZILI, Hugo Nigro. A Defesa dos Interesses Difusos em Juízo. 20. ed. rev. ampliada e atual. São Paulo: Saraiva, 2007.

MEIRELLES, Hely Lopes; WALD, Arnoldo; MENDES, Gilmar Ferreira. Mandado de segurança e ações constitucionais. 32. ed. São Paulo: Malheiros, 2009.

MENDES, Aluísio Gonçalves de Castro. Ações coletivas e meios de resolução coletiva de conflitos no direito comparado e nacional.4. ed. rev. atual. e ampliada. São Paulo: Revista dos Tribunais, 2014.

MENDES, Gilmar Ferreira; BRANCO, Paulo Gustavo Gonet. Curso de Direito Constitucional. 9. ed. rev. e atual. São Paulo: Saraiva, 2014.

MEZZAROBA, Orides. Introdução ao Direito Partidário Brasileiro. Rio de Janeiro: Lumen Juris, 2003. 
MOREIRA, José Carlos Barbosa. Ações Coletivas na Constituição Federal de 1988. Revista de Processo. vol. 61, jan. 1991. p. 187.

OLIVEIRA, Mauro Márcio. Fontes de informações sobre a Assembléia Nacional Constituinte de 1987: quais são, onde busca-las e como usá-las. Brasília: Senado Federal, 1993. Disponível em: http://www2.camara.leg.br/atividadelegislativa/legislacao/Constituicoes_Brasileiras/constituicao-cidada/publicacoes/panorama-dofuncionamento-geral. Acesso em 10 abr. 2018.

PASSOS, José Joaquim Calmon de. Mandado de Segurança Coletivo, Mandado de Injunção, Habeas Data (Constituição e Processo). Rio de Janeiro: Forense, 1989.

PRADE, Péricles. Conceito de Interesses Difusos. 2. ed. São Paulo: Revista dos Tribunais, 1987.

QUINTAS, Fábio Lima. O juiz como última instância da Administração Pública: o impacto do ativismo judicial na ordenação do direito e na função administrativa. Revista Brasileira de Estudos Constitucionais, Belo Horizonte, v. 5, n. 20, p. 245-261, out./dez. 2011.

QUINTAS, Fábio Lima. Um ensaio sobre a função da lei no Estado Democrático de Direito: uma reflexão a partir da obra de Neil MacCormick. Brasília: IDP, 2014. 76p. Disponível em: <http://dspace.idp.edu.br:8080/xmlui/handle/123456789/1589>. Acesso em: 27 abr. 2019.

SALGADO, Eneida Desiree. A Representação Política e sua Mitologia. Paraná Eleitoral: Revista Brasileira de Direito Eleitoral e Ciência Política. Paraná, v. 1, n. 1. 2012. p. 25-40. Disponível em: http://revistas.ufpr.br/pe/article/view/42727/25885. Acesso em: 15 nov. 2017.

SANTOS, Ernane Fidélis dos. Mandado de segurança individual e coletivo: legitimação e interesse. In: TEIXEIRA, Sálvio de Figueiredo (Coord.). Mandados de segurança e de injunção. São Paulo: Saraiva, 1990.

SANTOS, Ernane Fidélis dos. Manual de Direito Processual Civil: Procedimentos Especiais Codificados e da Legislação Esparsa, Jurisdição Contenciosa e Jurisdição Voluntária. Vol. 3. 14. ed. São Paulo: Saraiva, 2011.

SILVA, José Afonso da. Curso de Direito Constitucional Positivo. 25. ed. rev. e atual. nos termos da Reforma Constitucional, Emenda Constitucional n. 48, de 10.8.2005. São Paulo: Malheiros, 2005.

TUCCI, José Rogério Cruz e. “ClassAction” e Mandado de Segurança Coletivo: Diversificações Conceptuais. São Paulo: Saraiva, 1990.

ZANETI JR., Hermes. O “Novo” Mandado de Segurança Coletivo. Salvador: Juspodivm, 2013.

ZAVASCKI, Teori Albino. Processo Coletivo: Tutela de Direitos Coletivos e Tutela Coletiva de Direitos. 7. ed. São Paulo: Revista dos Tribunais, 2017. 